\title{
Erratum to: The quantitative real-time PCR applications in the monitoring of marine harmful algal bloom (HAB) species
}

\author{
Antonella Penna • Luca Galluzzi
}

Published online: 2 February 2013

(C) Springer-Verlag Berlin Heidelberg 2013

Erratum to: Environmental Science and Pollution Research

DOI 10.1007/s11356-012-1377-z

The correct name of the first author is Antonella Penna.

The correct name of the second author is Luca Galluzzi.

The online version of the original article can be found at http://dx.doi.org/ 10.1007/s11356-012-1377-z.

A. Penna $(\bowtie) \cdot$ L. Galluzzi

Department of Biomolecular Sciences,

University of Urbino, Viale Trieste 296,

Pesaro, Italy

e-mail: antonella.penna@uniurb.it 